\title{
NUTRICEUTICAL POTENTIAL OF Pleurotus tuber-regium SCLEROTIUM
}

\author{
REGINALD C. OHIRI \\ Department of Biochemistry, Faculty of Science, University of Port \\ Harcourt;East-West Road, Choba, Rivers State, Nigeria; \\ e-mail: raycohiri@yahoo.com; reginald.ohiri@uniport.edu.ng
}

The aim of the study was to determine the composition of the sclerotium of Pleurotus tuber-regium and to analyze its nutritional potential. Major minerals and micronutrients content of the P. tuber-regium sclerotium were determined. The study has shown fairly high concentrations of potassium and magnesium as major minerals with values of $60.66 \pm 4.13$ and $41.79 \pm 3.14 \mathrm{mg} / \mathrm{kg}$, while manganese and zinc were micronutrients with the highest values of $1.20 \pm 0.10$ and $0.95 \pm 0.07 \mathrm{mg} / \mathrm{kg}$. Glutamic acid and aspartic acid were also observed in high concentrations with values of $11.51 \pm 1.01$ and $5.52 \pm 0.86 \mathrm{mg} / \mathrm{kg}$. The mushroom powder of $P$. tuber-regium was a source for production of oil, which was analyzed by GC-MS method. Benzenedicarboxylic acid mono-(2-ethylhexyl) ester and benzenedicarboxylic acid butyl-cyclohexyl ester were volatile constituents predominating with percentage total of 78.7 and 5.2, respectively. It is concluded that the presence of mineral elements, amino acids and volatile components observed in this fungus indicated the presence of the nutritional potential in the sclerotia of $P$. tuber-regium.

Ke y wo rds: Pleurotus tuber-regium sclerotium, mineral elements, amino acids, volatile components, medicinal properties.

$\mathrm{G}$ lobally, the consumption of mushrooms has remained an alternative and affordable source of quality protein, mineral elements and other nutrients. While about $81.7 \%$ of such consumption are based on these nutritional benefits, 93.5 and $15.1 \%$ are based on palatability and medicinal properties respectively [1]. Unlike in Japan and China where medicinal properties of mushrooms are well documented, information on their medicinal applications in Africa are obtained from local herbalist who may not be able to document their finding or may not like to disclose the components of their preparations. Although must edible mushrooms are important sources of nutrients and relevant pharmacological compounds, information on the medicinal properties of non-edible and most wild mushrooms are scientifically inadequate. The presence of relevant health promoting compounds such as antioxidant, antimicrobial, anticancer, cholesterol lowering and immunostimulatory effects of some species of mushrooms have been reported [2]. These health enhancing properties have been attributed to the presence of some biologically active compounds such as glycolipids, shikimic acid derivatives, aromatic phenols, fatty acid derivatives, polyacetylamine, polyketides, nucleosides, sesterterpenes, and many other substances of different origins in some mushrooms [3]. One mushroom with a notable pharmacological history is the Pleurotus tuber-regium. $P$. tuber-regium is a wood consuming fungi that produces a dark brown storage tuber (sclerotium) whose circumference may grow to about $35 \mathrm{~cm}$. Though the sclerotium and the fruiting bodies are edible, the saprotrophic and nematophagous properties of the fruiting bodies have been reported [4], while the whitish interior of the sclerotium is use in the western part of Africa as thickener and flavouring agent in the preparation of soups. The purpose of this study is to reveal the nutritive properties of the sclerotium of $P$. tuber-regium and to identify the medicinal properties of its components.

\section{Materials and Methods}

Sample collection and preparation. Fresh sclerotium of $P$. tuber-regium was collected from its natural environment in Aluu community, about 10

(C) 2018 Ohiri R. C. This is an open-access article distributed under the terms of the Creative Commons Attribution License, which permits unrestricted use, distribution, and reproduction in any medium, provided the original author and source are credited. 
kilometres from the University of Port Harcourt in Nigeria. The mushroom was identified at the Faculty of Agriculture, University of Port Harcourt. A quantity of the sclerotium $(1.0 \mathrm{~kg})$ was thoroughly washed and air dried at room temperature for one (1) week in a clean dust free environment. The dried samples were peeled and sliced with a sterilized knife and ground into a fine smooth powder using Thomas Scientific, (Model 4) Wiley's mill.

Determination mineral elements and amino acid content. Major minerals and trace elements content of the sclerotium of $P$. tuber-regium were determined by the method of the Association of Official Analytical Chemists (A.O.A.C.) [5]. Nineteen of the twenty amino acids and tryptophan were determined by the methods of Benitez [6] and Robel [7] respectively.

GC-MS analysis of mushroom oil. Ground mushroom powder (100 g) was added to $3 \mathrm{dm}^{3}$ of distilled water and the oil obtained by hydro-distillation was collected into hexane and concentrated by evaporation at room temperature. The oil was analysed using a combined gas chromatograph model HP 6890 and mass spectrometer model 5973 (Agilent Tech.) fitted with a capillary column HP-5 MS (5\% phenylmethylsiloxane) $30.0 \mathrm{~m} \times 250 \mu \mathrm{m} \times 0.25 \mu \mathrm{m}$, using Helium as a carrier gas at initial column temperature $120{ }^{\circ} \mathrm{C}$ for $5 \mathrm{~min}$. Thereafter, the column temperature was increased at $5{ }^{\circ} \mathrm{C}$ per minutes to $320^{\circ} \mathrm{C}$ and held for $5 \mathrm{~min}$. Electron impact ionization for mass spectroscopy was done at ionization energy of $70 \mathrm{eV}$. The oil was diluted with $98 \%$ hexane and $2 \mu \mathrm{l}$ of the diluted sample was automatically

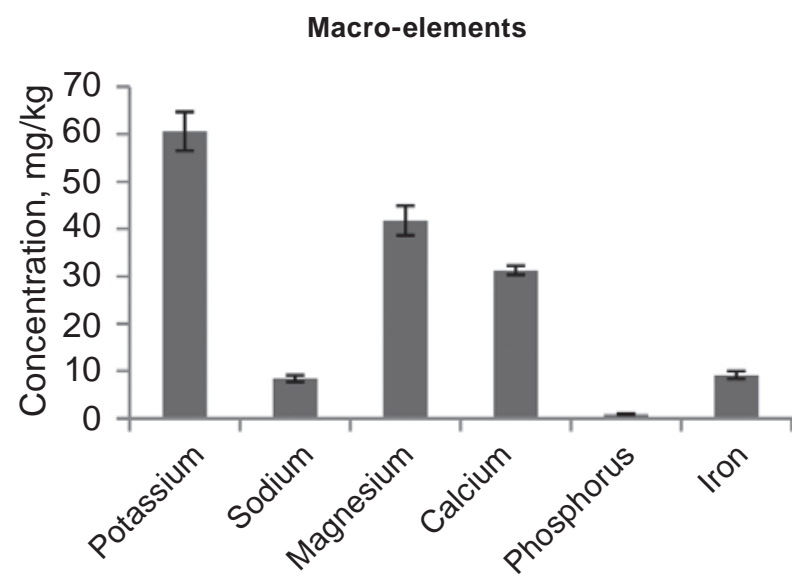

Fig. 1. Major-mineral concentration $(\mathrm{mg} / \mathrm{kg})$ in sclerotium of P. tuber-regium. Values plotted are means $\pm S D$ of triplicate determination injected into Agilent Tech. model 5973 mass spectrometer. The constituent compounds were identified using the Chem-Office software attached to the MS library. The names and structures of the component oils were confirmed using the database of National Institute of Standard and Technology (NIST).

Statistical analysis. Data are presented as mean \pm standard deviation (SD) of triplicate determinations. Mean values were obtained using 2010 Microsoft Excel software program.

\section{Results and Discussion}

The result of this study showed the presence of major-minerals, micronutrients, amino-acids, and seventeen volatile constituents in sclerotium of P. tuber-regium. From the result of the macro-elements (Fig. 1), potassium had the highest concentration with a value of $60.66 \pm 4.13 \mathrm{mg} / \mathrm{kg}$ followed by magnesium and calcium, with values of $41.79 \pm 3.14$ and $31.24 \pm 0.96 \mathrm{mg} / \mathrm{kg}$ respectively, while phosphorus had the lowest concentration with a value of $0.83 \pm 0.14 \mathrm{mg} / \mathrm{kg}$. Amongst the micronutrients (Fig. 2), manganese, zinc and nickel had the highest concentrations with values of $1.20 \pm 0.10 ; 0.95 \pm 0.07$ and $0.27 \pm 0.03 \mathrm{mg} / \mathrm{kg}$ respectively, while cobalt and cadmium had the lowest concentration with values of $0.05 \pm 0.00$ and $0.06 \pm 0.01 \mathrm{mg} / \mathrm{kg}$ respectively.

Glutamic acids was the highest amino acid observed in this mushroom with a value of $11.51 \pm 1.01 \mathrm{mg} / \mathrm{kg}$, followed by aspartic acid, arginine and leucine with values of $5.52 \pm 0.86$, $4.93 \pm 0.71$ and $3.78 \pm 0.28 \mathrm{mg} / \mathrm{kg}$ respectively. Although glutamine and asparagine were not detec-

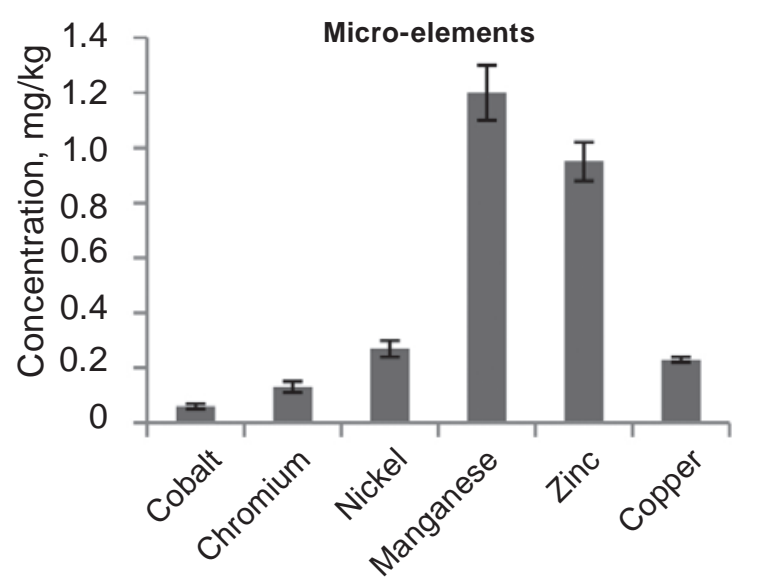

Fig. 2. Micronutrients concentration $(\mathrm{mg} / \mathrm{kg})$ in sclerotium of P. tuber-regium. Values plotted are means $\pm S D$ of triplicate determination 


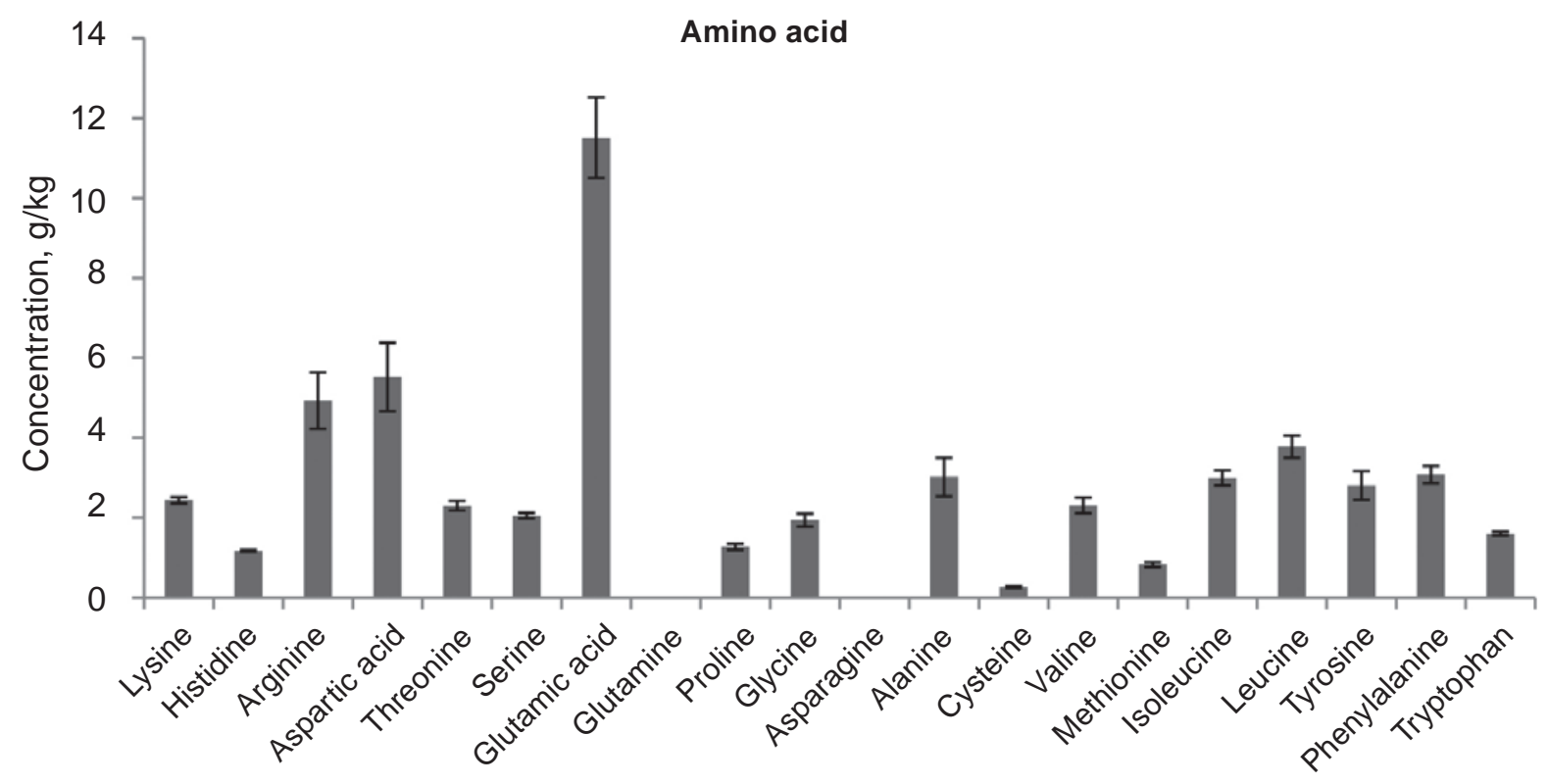

Fig. 3. Amino-acid concentration ( $\mathrm{mg} / \mathrm{kg}$ ) in sclerotium of P. tuber-regium. Values plotted are means $\pm S D$ of triplicate determination

ted in the sclerotium of $P$. tuber-regium, cysteine had the lowest concentration with a value of $0.27 \pm 0.03 \mathrm{mg} / \mathrm{kg}$ followed by methionine with a value of $0.83 \pm 0.06 \mathrm{mg} / \mathrm{kg}$ (Fig. 3).

The seventeen volatile constituents from the sclerotium of $P$. tuber-regium, their gas chromatogram and individual spectrum are shown in Table, Fig. 4 and Figs. 5, $A-P$ respectively. 1,2-Benzenedicarboxylic acid, mono (2-ethylhexyl) ester was the most predominant volatile component observed in this mushroom with a $\mathrm{R}_{\mathrm{T}}$ of 23.485 min and a per- centage total 78.713, followed by 1,2-Benzenedicarboxylic acid, butyl cyclohexyl ester with a $\mathrm{R}_{\mathrm{T}}$ of $16.147 \mathrm{~min}$ and a percentage total of 5.157, while Farnesol isomer A and cis-Vaccenic acid had $\mathrm{R}_{\mathrm{T}}$ 29.739 and $24.243 \mathrm{~min}$ and percentage total of 2.021 and 1.955 respectively. These four major constituents represent $87.846 \%$ of the total volatile constituents in the sclerotium of $P$. tuber-regium, while the thirteen minor constituents represent $12.154 \%$.

The high concentration of potassium and magnesium observed in this mushroom shows it ability

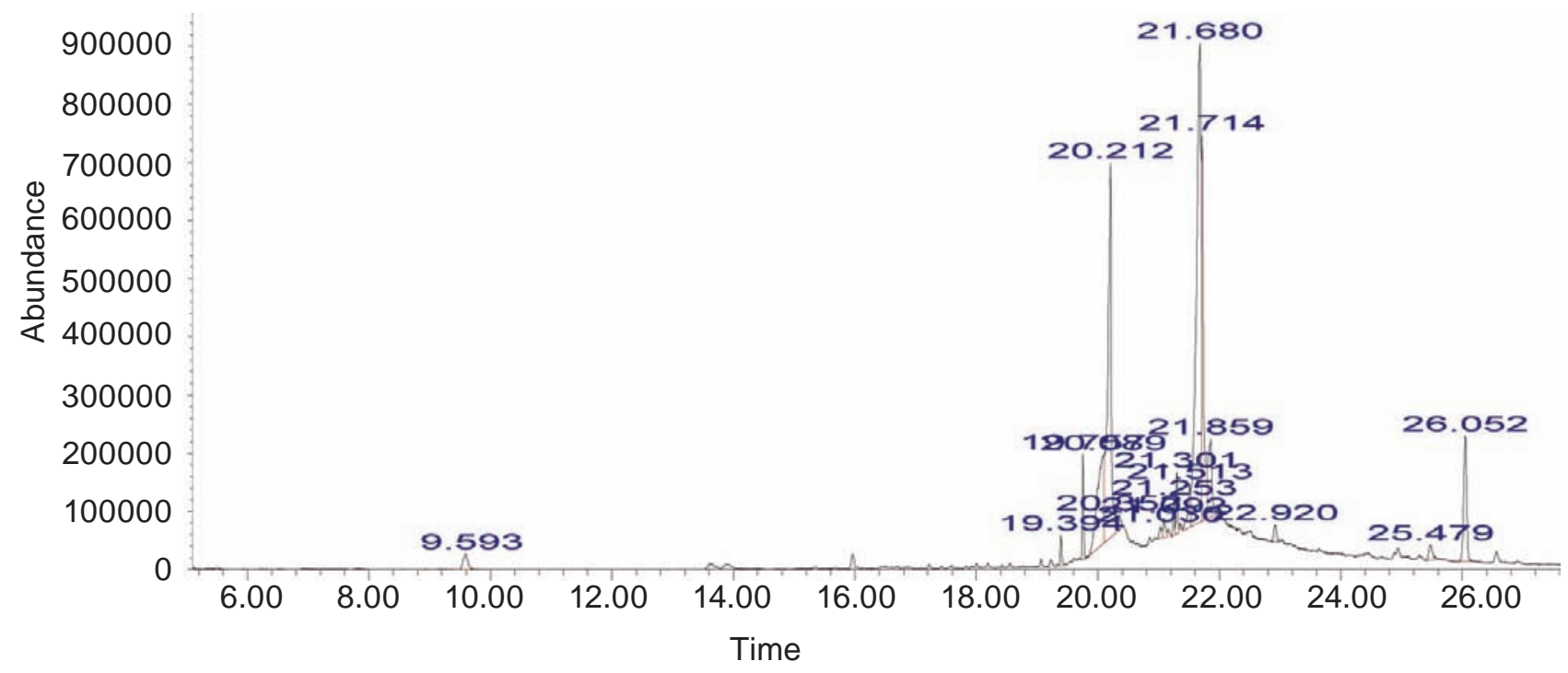

Fig. 4. Gas Chromatogram of the volatile components of sclerotium of P. tuber-regium 
Results of GC-MS analysis of volatile components of sclerotium of P. tuber-regium

\begin{tabular}{|c|c|c|c|c|c|c|}
\hline $\mathrm{S} / \mathrm{N}$ & Compound & $\begin{array}{l}\text { Retention } \\
\text { time, min }\end{array}$ & $\begin{array}{l}\text { Percen- } \\
\text { tage of } \\
\text { the total }\end{array}$ & Peak area & $\begin{array}{l}\text { Molecular } \\
\text { formula }\end{array}$ & $\begin{array}{c}\text { Molecular } \\
\text { weight, } \\
\text { g/mol }\end{array}$ \\
\hline 1 & $\begin{array}{l}\text { 3-Chloropropionic acid, } \\
\text { heptadecyl ester }\end{array}$ & 12.890 & 0.657 & 601352 & $\mathrm{C}_{19} \mathrm{H}_{37} \mathrm{ClO}_{2}$ & 332.949 \\
\hline 2 & 1-Nonadecene & 15.273 & 0.726 & 664796 & $\mathrm{C}_{19} \mathrm{H}_{38}$ & 266.5050 \\
\hline 3 & $\begin{array}{l}\text { 1,2-Benzenedicarboxylic acid, } \\
\text { butyl cyclohexyl ester }\end{array}$ & 16.147 & 5.157 & 1129778 & $\mathrm{C}_{18} \mathrm{H}_{24} \mathrm{O}_{4}$ & 304.3808 \\
\hline 4 & Dibutyl phthalate & 16.648 & 1.885 & 1725265 & $\mathrm{C}_{16} \mathrm{H}_{22} \mathrm{O}_{4}$ & 278.3400 \\
\hline 5 & $\begin{array}{l}\text { Pentadecanoic acid, } \\
\text { 14-methyl-, methyl ester }\end{array}$ & 16.720 & 1.021 & 934655 & $\mathrm{C}_{17} \mathrm{H}_{34} \mathrm{O}_{2}$ & 270.4507 \\
\hline 6 & Bromoacetic acid, hexadecyl ester & 17.406 & 0.545 & 499276 & $\mathrm{C}_{18} \mathrm{H}_{35} \mathrm{BrO}_{2}$ & 363.373 \\
\hline 7 & $\begin{array}{l}\text { 1,2-Benzenedicarboxylic } \\
\text { acid, butyl decyl ester }\end{array}$ & 18.101 & 0.512 & 468603 & $\mathrm{C}_{22} \mathrm{H}_{34} \mathrm{O}_{4}$ & 362.5030 \\
\hline 8 & 11-Octadecenoic acid, methyl ester & 18.485 & 1.626 & 1488668 & $\mathrm{C}_{19} \mathrm{H}_{36} \mathrm{O}_{2}$ & 296.4879 \\
\hline 9 & $\begin{array}{l}\text { Acetic acid, } \\
\text { 4-(7-methylydenebicyclo[3.3.1] } \\
\text { non-2-en-3 yloxy)butyl ester }\end{array}$ & 18.736 & 0.838 & 767166 & $\mathrm{C}_{16} \mathrm{H}_{24} \mathrm{O}_{3}$ & 264.3510 \\
\hline 10 & Methyl 2-hydroxy-eicosanoate & 20.091 & 0.758 & 694256 & $\mathrm{C}_{21} \mathrm{H}_{42} \mathrm{O}_{3}$ & 342.556 \\
\hline 11 & Didodecyl phthalate & 20.504 & 1.302 & 1191513 & $\mathrm{C}_{32} \mathrm{H}_{54} \mathrm{O}_{4}$ & 502.7688 \\
\hline 12 & $\begin{array}{l}\text { Cyclodecacyclotetradecene, 1,2,3,4,5,6, } \\
\text { 7,8,9,10,11,12,13,14,15,16,17,18,19, } \\
\text { 20-eicosahydro- }\end{array}$ & 22.000 & 1.168 & 1069292 & $\mathrm{C}_{22} \mathrm{H}_{40}$ & 304.5530 \\
\hline 13 & 1-Eicosene & 22.636 & 1.095 & 1002144 & $\mathrm{C}_{20} \mathrm{H}_{40}$ & 280.5316 \\
\hline 14 & $\begin{array}{l}\text { 1,2-Benzenedicarboxylic acid, } \\
\text { mono (2-ethylhexyl) ester }\end{array}$ & 23.485 & 78.713 & 72060173 & $\mathrm{C}_{16} \mathrm{H}_{22} \mathrm{O}_{4}$ & 278.3435 \\
\hline 15 & 2-Methyl-7-nonadecene & 23.587 & 0.021 & 19336 & $\mathrm{C}_{20} \mathrm{H}_{40}$ & 280.5320 \\
\hline 16 & cis-Vaccenic acid & 24.243 & 1.955 & 1790129 & $\mathrm{C}_{18} \mathrm{H}_{34} \mathrm{O}_{2}$ & 282.4610 \\
\hline 17 & Farnesol isomer A & 29.739 & 2.021 & 1849743 & $\mathrm{C}_{15} \mathrm{H}_{26} \mathrm{O}$ & 222.3663 \\
\hline
\end{tabular}

to absorb and bioaccumulate these elements from its growth medium. The result of this study corroborate the findings of Falandysz and Borovička [8], which reported the ability of macro-fungi to accumulate extremely high concentrations of metallic elements even when grown on a low metal containing medium. Mallikarjuna et al. [9], also reported high concentrations of metallic elements like potassium and magnesium in wild Lentinus cladopus, and Pleurotus djamor and cultivated Lentinula edodes, Pleurotus florida mushrooms. Because of its high potassium content, the consumption of the sclerotium of $P$. tuber-regium may help in the regulation of acid-base balance, nerve impulse transmission and also in muscle contraction [10]. Its high magnesium content shows that the consumption of this mushroom may be relevant in some enzymatic reactions, protein syntheses, cyclic AMP formation and also in neuromuscular transmission [11]. The fairly high concentration of manganese and zinc observed in this study contradicts the finding of Mallikarjuna et al. [9], which reported a relatively low concentration of manganese in all their four studied mushrooms. This indicates that mineral element content of a mushroom may be a factor of mushroom variety, part of mushroom analysed, or the growth medium 

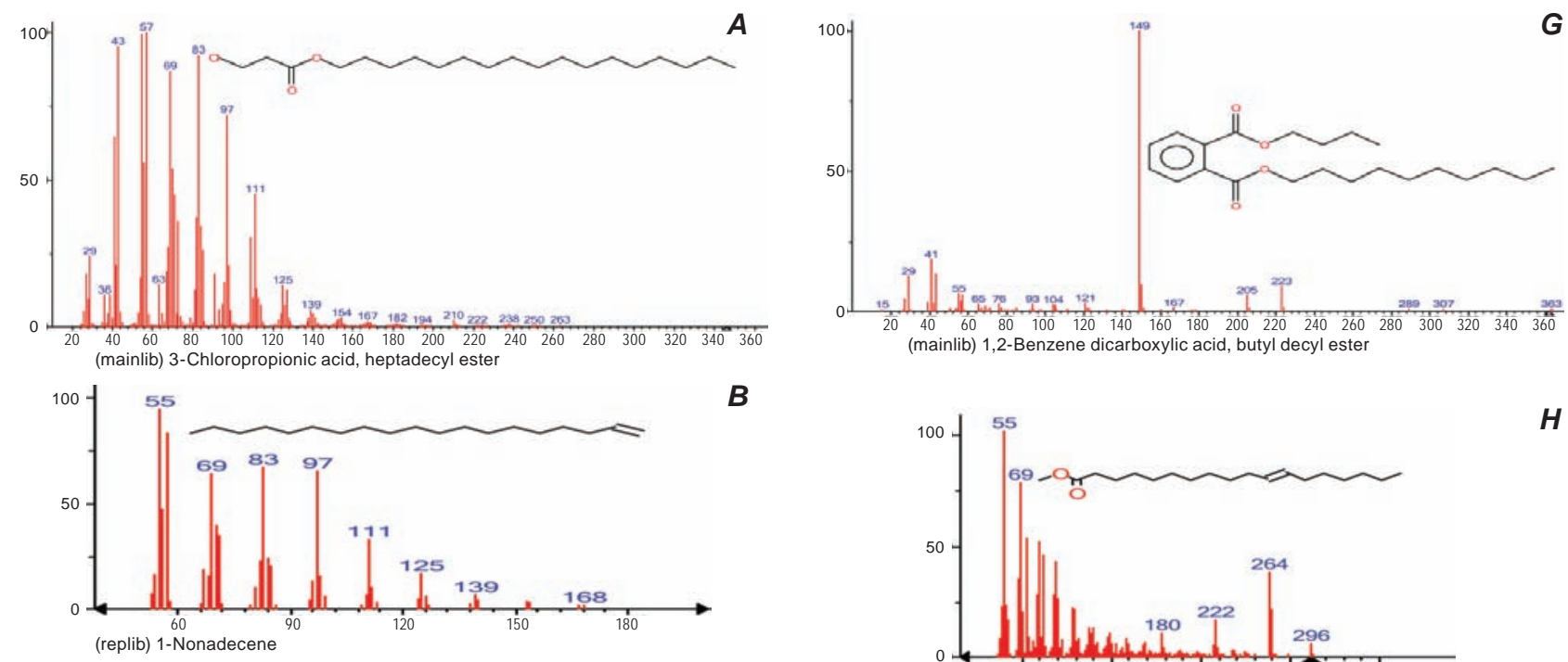

$B$
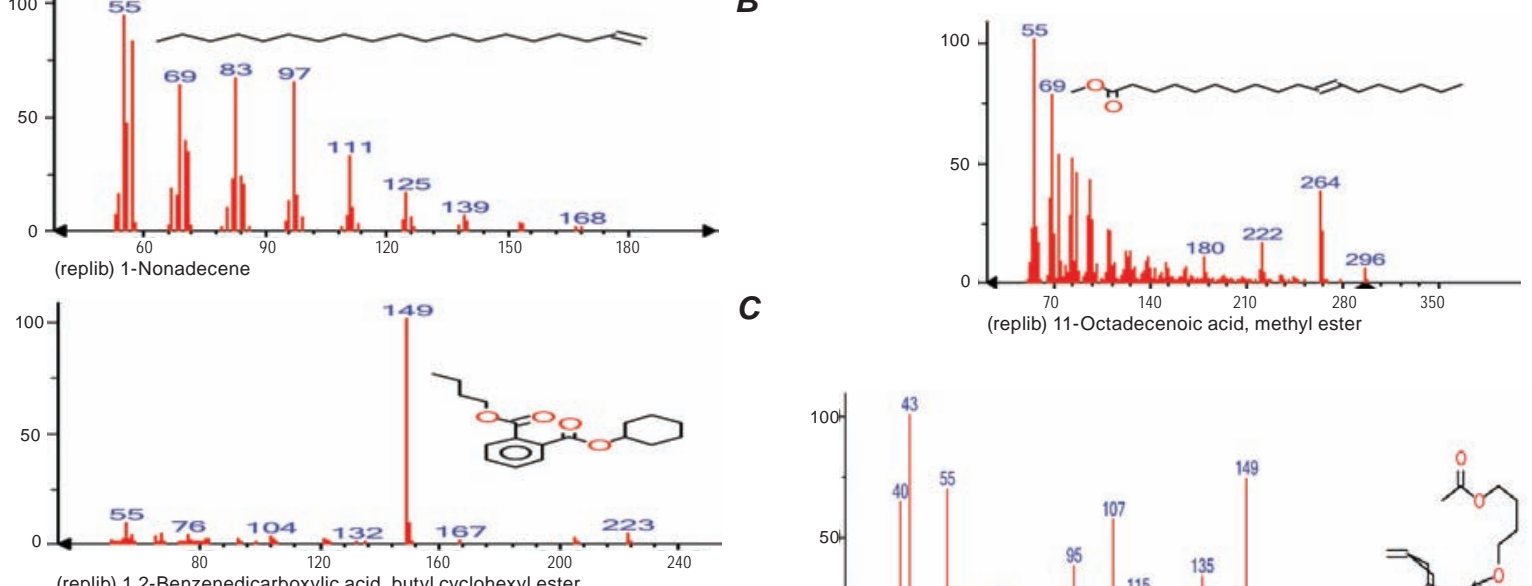

C

$\boldsymbol{H}$
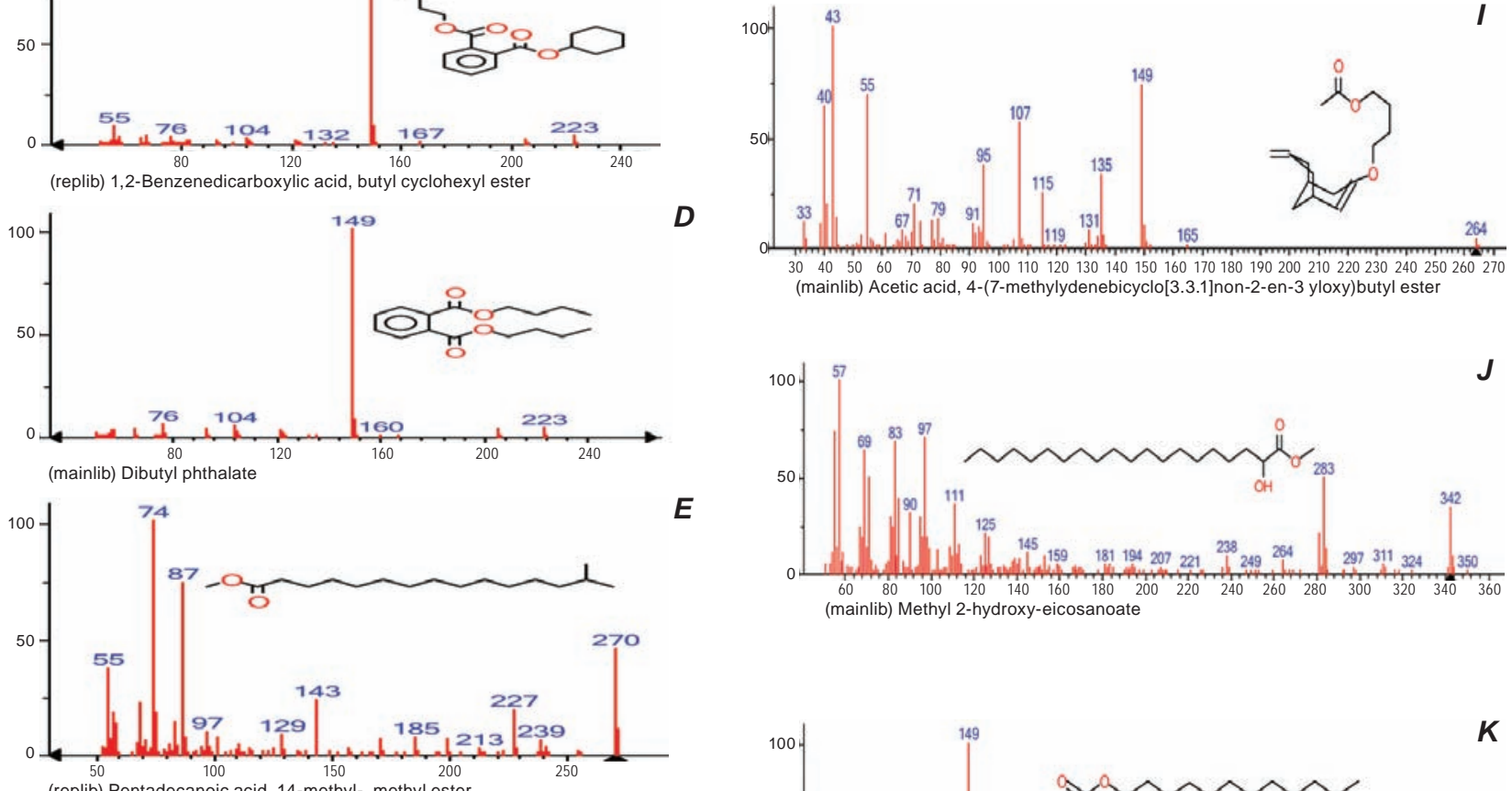

E
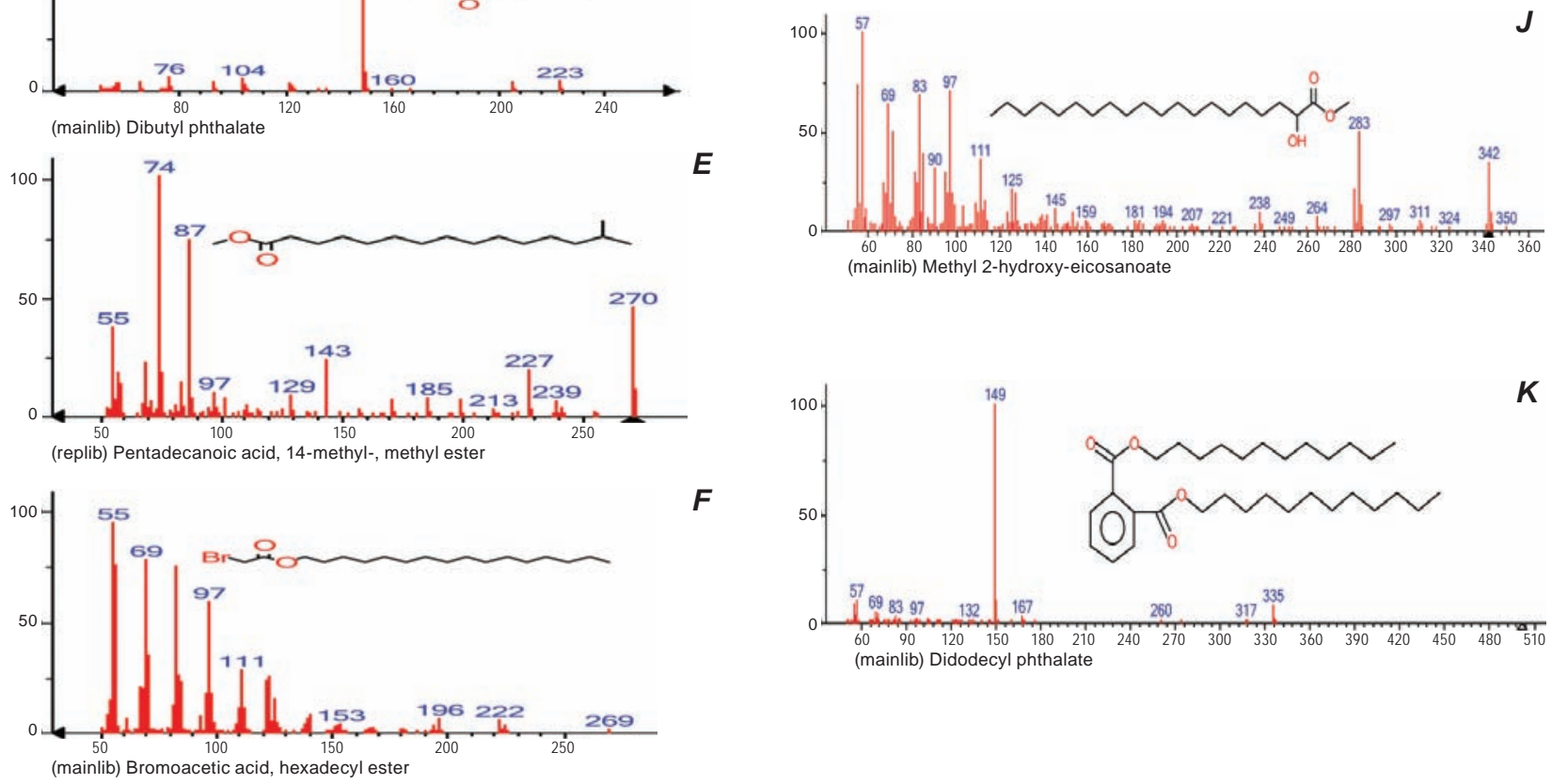

Fig. 5. Mass spectrum: A - 3-Chloropropionic acid, heptadecyl ester (RT: 12.890); B - 1-Nonadecene (RT: 15.273); $\boldsymbol{C}$ - 1,2-Benzenedicarboxylic acid,butyl cyclohexyl ester (RT:16.147); D - Dibutyl phthalate (RT: 16.648); $\boldsymbol{E}$ - Pentadecanoic acid, 14-methyl-, methyl ester (RT: 16.720); F - Bromoacetic acid, hexadecyl ester (RT: 17.406); G - 1,2-Benzene dicarboxylic acid, butyl decyl ester (RT: 18.101); H - 11-Octadecenoic acid, methyl ester (RT: 18.485); I - Acetic acid, 4-(7-methylydenebicyclo[3.3.1]non-2-en-3 yloxy)butyl ester (RT: 18.736); $\boldsymbol{J}$ - Methyl 2-hydroxy-eicosanoate (RT: 20.091); K -Didodecyl phthalate (RT: 20.504) 

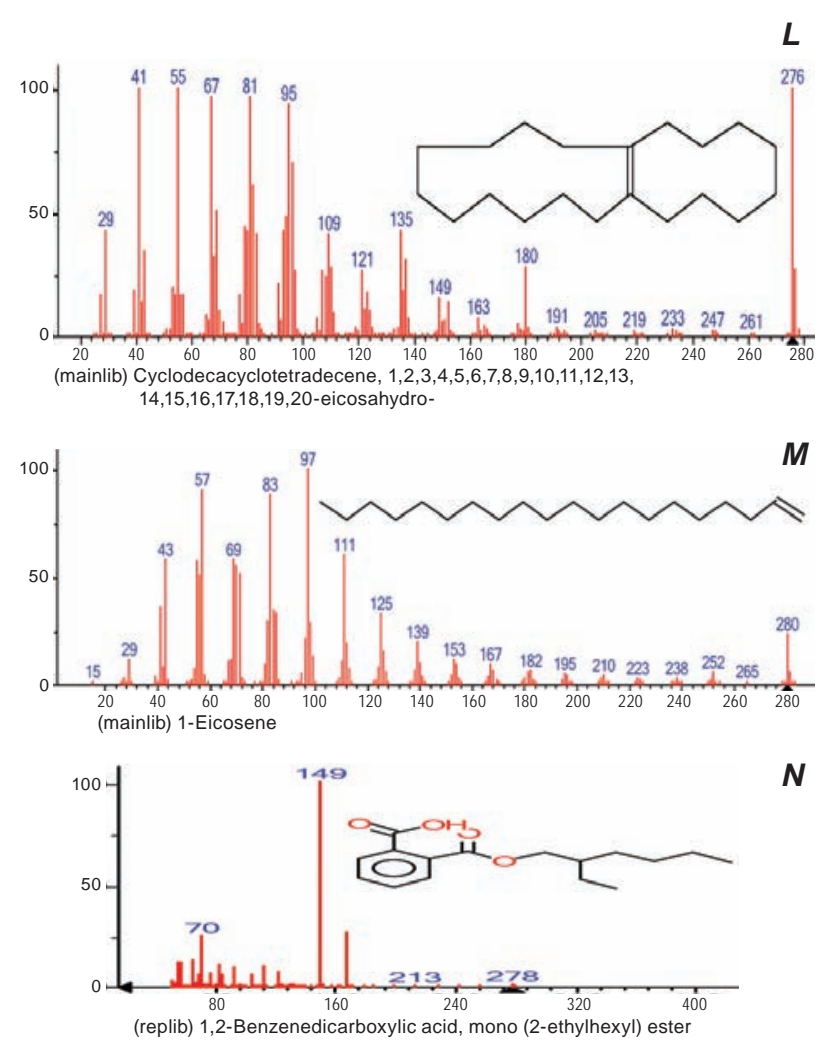

$N$
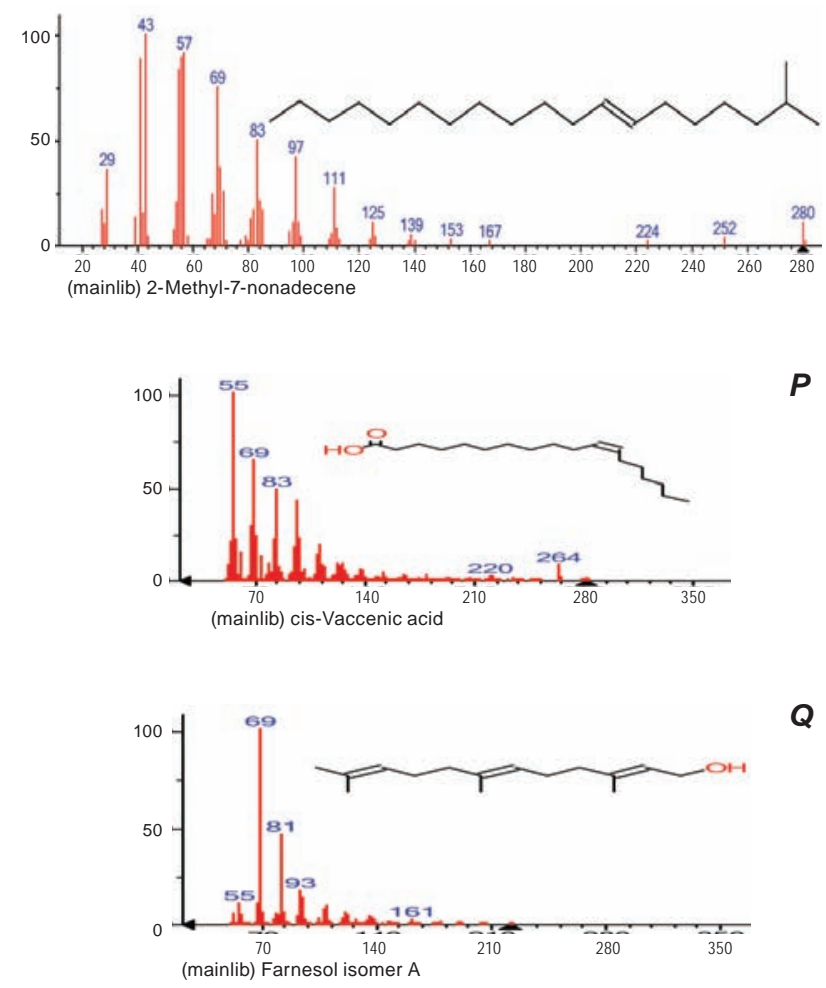

Fig. 5. Mass spectrum: L - Cyclodecacyclotetradecene, 1,2,3,4,5,6,7,8,9,10,11,12,13,14,15,16,17,18,19,20-eicosahydro- (RT: 22.000); $\boldsymbol{M}$ - 1-Eicosene (RT: 22.636); $\boldsymbol{N}$-1,2-Benzenedicarboxylic acid, mono (2-ethylhexyl) ester (RT: 23.485); $\boldsymbol{O}$ - 2-Methyl-7-nonadecene (RT: 23.587); $\boldsymbol{P}$ - cis-Vaccenic acid (RT: 24.243); $\boldsymbol{Q}$ - Farnesol isomer A (RT: 29.739)

of the mushroom. As a micro-element, manganese acts either as a cofactor activating a number of enzymes thereby forming metal-enzyme complexes or as an integral part of some metalloenzymes [12], while zinc has been reported to increase the activities of more than 70 enzymes [13]. Moreover, a retarded DNA, RNA and protein synthesis and subsequent impairment in cellular division, growth and repair of worn-out tissues has also been reported in zinc deficient animals [14].

Amongst the eighteen amino acids observed in this mushroom, glutamic acid and aspartic acid were in fairly high concentrations. This contradicts the findings of Oyetayo et al. [15], which reported leucine as the most abundant amino acid in both wild and cultivated varieties of Pleurotus sajor-caju. They subsequently stated that amino acid concentration of a mushroom is a function of mushroom variety and the specific part of the mushroom that was selected for analysis [22]. Since glutamic acid is known for its contribution in the flavouring of foods [16], its observed high concentration shows that this mushroom not only serve as a soup thicker but also as a flavour enhancer. Although glutamic acid is a non-essential amino acid, its role as an excitatory neurotransmitter makes it one of the most abundant molecules in the brain [17]. Because of its role in synaptic plasticity, glutamate is involved in cognitive functions such as learning and memory in the brain [17]. About 95\% of the dietary glutamate is metabolized by intestinal cells [18], thereby allowing the absorption and addition of only $5 \%$ of dietary glutamate to the concentration synthesized by the body. This indicates that the ingestion of natural food substances of high glutamic acid concentration as observed in this mushroom should be encouraged.

As a non-essential proteinogenic amino acid, the high concentration of aspartic acid in this mushroom may not be of much importance to human consumers. However, Aspartic acid has been reported to acts as hydrogen acceptor in a chain of ATP synthase catalysed reactions, the role of its carboxylate anion (aspartate) as a metabolite in the urea cycle and its activity in gluconeogenesis has been reported [19]. In the malate-aspartate shuttle, aspartate carries reducing equivalents, which generates malic acid de- 
rivatives in the enzymatic conversion of aspartate to oxaloacetate [19]. The donation of a nitrogen atom in the biosynthesis of inosine also reveals the relevance of aspartate in purine synthesis [19]. The presence of arginine as the third most predominant amino acid observed in this reflects the nutritional importance of this mushroom and its relevance to human health. The role of arginine in cell division, wound healing, immune function, the release of hormones and the removal of ammonia from the body has been reported [20]. Reports also indicates that adequate arginine concentration in the body can reduce the repair time of damaged tissue and also enhances the healing of fracture and other bone injuries [20]. As a precursor for the synthesis of nitric oxide (NO), arginine has been reported to decrease blood pressure in clinical hypertensive subjects [21].

1,2-Benzenedicarboxylic acid, mono (2-ethylhexyl) ester was the most predominant of the seventeen different compounds detected in the GC-MS analysis of the volatile component of this mushroom. As a phthalates, this compound has been under severe criticism. Exposure to high doses of phthalates to rats has been reported to cause both changes in hormonal concentration and birth defects [22], while those fed with high concentrations of specific phthalates showed hepatic and testicular damage [5]. Based on this facts, World Health Organisation (WHO), European Commission (EC) and International Agency for Research on Cancer (IARC) listed di(2-ethylhexyl) phthalate as a possible carcinogen [23]. However, studies on primates revealed that the carcinogenic mechanism of di(2ethylhexyl) phthalate is rodent specific and thus humans are not susceptible to such effect [23]. Sequel to this findings, the carcinogen classification of $\operatorname{di}(2-$ ethylhexyl) phthalate was withdrawn. Kannabiran et al. [24], reported cytotoxic activity of the pure 1,2benzene dicarboxylic acid, mono 2- ethylhexyl ester derived from marine actinomycete Streptomyces sp. VITSJK8 on mouse embryonic fibroblast (NIH 3T3), human keratinocyte (HaCaT) normal cell lines, human hepatocellular liver carcinoma (HepG 2) and human breast adenocarcinoma (MCF-7) cell lines. They concluded that 1,2-benzene dicarboxylic acid, mono 2-ethylhexyl ester exhibited potential cytotoxic effect against HepG 2 and MCF-7 cancer cell lines [24], indicating that 1,2-benzene dicarboxylic acid, mono 2-ethylhexyl ester and other phthalate esters such as 1,2-Benzenedicarboxylic acid, butyl cyclohexyl ester may be further explored for the treatment and management of cancer.

Farnesol is a non-irritant, non-bacteriostatic essential oil that occurs in plants such as star anise, cassia, musk seed, balsam, citronella and also in rose. It action as pheromone for most insects, and as a natural pesticide for termites [25], shows its role in the protection of this mushroom from termites and other insects. The use of Farnesol to emphasize the aroma of perfumes is based on its activity as a co-solvent that regulates the volatility of the component aromas of perfumes, [17], while its antibacterial property makes it a potential deodorant in cosmetic products [26]. Farnesol and its derivatives has been reported as important starter in the synthesis of both natural and artificial organic compounds [27]. Phosphate activated derivatives of farnesol in both plants and animals are used in the synthesis of acyclic sesquiterpenoids, which doubles to form a 30 -carbon squalene, that later serves as a precursor for the synthesis of steroids [28]. Though farnesol has been reported to act as a quorum sensing molecule that inhibits filamentation in the opportunistically pathogenic fungus Candida albicans [28], its chemopreventative and anti-tumor properties has also been reported in rats [29]. As an omega-7 fatty acid, the presence of cis-vaccenic acid in this mushroom provides a major source for the extraction of this compound. Abbas et al. [30], reported the role of cis-vaccenic acid in the suppression of some adhesion molecules that are linked to atherosclerosis. They reported the ability of this compound to significantly suppress vascular cellular adhesion molecule-1 (VCAM-1) and intra cellular adhesion molecule-1 (ICAM-1) in human microvascular endothelial cells (HMECs), thereby making cis-vaccenic acid a possible agents in the treatment and management of atherosclerosis [30].

In conclusion, the presence and nutriceutical potentials of the mineral elements, amino acids and the volatile components observed in this mushroom indicates that the consumption of this mushroom or its extracts may aid in the treatment and management of some nutrient deficiency induced disease conditions. 


\section{НУТРИЦЕВТИЧНИЙ ПОТЕНЦІАЛ СКЛЕРОЦІЮ Pleurotus tuber-regium}

\author{
R. C. Ohiri
}

Department of Biochemistry, Faculty of Science, University of Port Harcourt; EastWest Road, Choba, Rivers State, Nigeria; e-mail: raycohiri@yahoo.com; reginald.ohiri@uniport.edu.ng

Метою дослідження було визначення складу склероцію Pleurotis tuber-regium та аналіз його нутрицевтичного потенціалу. Під час визначення вмісту макро- та мікроелементів P. tuber-regium встановлено досить високі концентрації калію і магнію зі значеннями $60,66 \pm 4,13$ i 41,79 $\pm 3,14$ мг/кг, а також марганцю і цинку $-1,20 \pm 0,10$ і 0,95 \pm 0,07 мг/кг, відповідно. Глутамінова та аспарагінова кислоти також спостерігалися у високих концентраціях iз величинами $11,51 \pm 1,01$ i $5,52 \pm 0,86$ мг/кг. Методом ГХ/МС-аналізу олійної фракції, що була одержана зі склероцію P. tubber-regium, охарактеризовано 17 летючих компонентів, серед яких переважали моно- (2-етилгексил) естер бензолдикарбонової кислоти та бутилциклогексиловий ефір бензолдикарбонової кислоти із загальним співвідношенням 78,7 та 5,2\%, відповідно. Дійшли висновку, що високий вміст мінеральних елементів, амінокислот та летючих компонентів у досліджених зразках, вказує на поживні та лікувальні властивості склероцію P. tuber-regium.

К л ючов і сло в а: Pleurotus tuber-regium, мікроелементи, амінокислоти, летючі компоненти, лікарські властивості.

\section{НУТРИЦЕВТИЧЕСКИЙ ПОТЕНЦИАЛ СКЛЕРОЦИЯ Pleurotus tuber-regium}

\author{
R. C. Ohiri \\ Department of Biochemistry, Faculty \\ of Science, University of Port Harcourt; East- \\ West Road, Choba, Rivers State, Nigeria; \\ e-mail: raycohiri@yahoo.com; \\ reginald.ohiri@uniport.edu.ng
}

Целью работы было определение состава склероция Pleurotus tuber-regium и анализ его нутрицевтического потенциала. При определении макро- и микроэлементов P. tuber-regium было обнаружено высокое содержание калия и магния, которое составляло $60,66 \pm 4,13$ и $41,79 \pm 3,14$ мг/кг, а также марганца и цинка $1,20 \pm 0,10$ и 0,95 $\pm 0,07$ мг/кг, соответственно. Кроме того, обнаружено высокое содержание глутаминовой и аспарагиновой кислот: $11,51 \pm 1,01$ и 5,52 \pm 0,86 мг/кг. Методом ГХ/MCанализа масляной фракции, полученной из склероция P. tuber-regium, охарактеризовано 17 летучих компонентов, среди которых преобладали моно- (2-этилгексил) эфир бензолдикарбоновой кислоты и бутилциклогексиловый эфир бензолдикарбоновой кислоты с общим содержанием 78,7 и 5,2\%, соответственно. Сделан вывод, что высокое содержание минеральных элементов, аминокислот и летучих компонентов в исследуемых образцах, свидетельствуют о питательных и лечебных свойствах склероция P. tuber-regium.

К лючевы е слова: Pleurotus tuberregium, микроэлементы, аминокислоты, летучие компоненты, лекарственные свойства. 


\section{References}

1. Ayodele SM, Akpaja EO, Adamu Y. Some edible and medicinal mushrooms found in Igala land in Nigeria and their sociocultural and ethnomycological uses. Proceeding of the 5th International Medicinal Mushroom Conference, Nantong, China. 2009; P. 526-531.

2. Mau JL, Chang CN, Huang SJ, Chen CC. Antioxidant properties of methanolic extract from Grifola frondosa, Morchella esculenta and Termitomyces albuminosus mycelia. Food Chem. 2004; 87(1): 111-118.

3. Wasser SP, Weis AL. Therapeutic effects of substances occurring in higher Basidiomycetes mushrooms: a modern perspective. Crit Rev Immunol. 1999; 19(1): 65-96.

4. Hibbett DS, Thorn RG. Nematode-Trapping in Pleurotus tuberregium. Mycologia. 1994; 86(5): 696-699.

5. Association of Official Analytical Chemists (A.O.A.C.). Official methods of analysis. 11th ed. Washington D.C. 1970.

6. Benitez LV. Amino acid and fatty acid profiles in aquaculture nutrition studies, In S. S. De Silva ed. Fish nutrition research in Asia. Proceedings of the third Asian fish nutrition network meeting. Asian Fish Society Special Publication 4. Asian Fisheries Society, Manila Philippines. 1989; p. 166.

7. Robel EJ. Ion-exchange chromatography for the determination of tryptophan. Anal Biochem. 1967; 18(3): 406-413.

8. Falandysz J, Borovička J. Macro and trace mineral constituents and radionuclides in mushrooms: health benefits and risks. Appl Microbiol Biotechnol. 2013; 97(2): 477-501.

9. Mallikarjuna SE, Ranjini A, Haware DJ, Vijayalakshmi MR, Shashirekha MN, Rajarathnam S. Mineral Composition of Four Edible Mushrooms. J Chem. 2013; 2013: 1-5.

10. Fregly MJ. Sodium and Potassium. In Olson RE, Broquist HP, Chichester CO, Darby WJ, Kolbye Jr, AC, Slavey, RM. eds. Present knowledge in nutrition 5th edition. Nutrition Foundation Inc. Washington D. C. 1984; p. 450.

11. Shils ME. Magnesium. In Olson RE, Broquist HP, Chichester CO, Darby WJ, Kolbye Jr, AC, Slavey, RM. eds. Present knowledge in nutrition 5th edition. Nutrition Foundation Inc. Washington D. C. 1984; pp. 442-443.
12. Hurley LS. Manganese. In Olson RE, Broquist HP, Chichester CO, Darby WJ, Kolbye Jr, AC, Slavey, RM. eds. Present knowledge in nutrition 5th edition. Nutrition Foundation Inc. Wsahington D. C., 1984; pp. 559-560.

13. Kfoury GA, Reinhold JG, Simonian SJ. Enzyme activities in tissues of zinc-deficient rats. $J$ Nutr. 1968; 95(1): 102-110.

14. Terhune MW, Sandstead HH. Decreased RNA polymerase activity in mammalian zinc deficiency. Science. 1972; 177(4043): 68-69.

15. Oyetayo FL, Akindahunsi AA, Oyetayo VO. Chemical profile and amino acids composition of edible mushrooms Pleurotus sajor-caju. Nutr Health. 2007; 18(4): 383-389.

16. van Lith SA, Navis AC, Verrijp K, Niclou SP, Bjerkvig R, Wesseling P, Tops B, Molenaar R, van Noorden CJ, Leenders WP. Glutamate as chemotactic fuel for diffuse glioma cells: are they glutamate suckers? Biochim Biophys Acta. 2014; 1846(1): 66-74.

17. McEntee WJ, Crook TH. Glutamate: its role in learning, memory, and the aging brain. Psychopharmacology (Berl). 1993; 111(4): 391401.

18. Reeds PJ, Burrin DG, Stoll B, Jahoor F. Intestinal glutamate metabolism. J Nutr. 2000; 130(4S Suppl): 978S-982S.

19. Nelson DL, Cox MM. Lehninger Principles of Biochemistry (3rd ed.), W. H. Freeman, New York. 2000.

20. Stechmiller JK, Childress B, Cowan L. Arginine supplementation and wound healing. Nutr Clin Pract. 2005; 20(1): 52-61.

21. Dong JY, Qin LQ, Zhang Z, Zhao Y, Wang J, Arigoni $\mathrm{F}$, Zhang W. Effect of oral L-arginine supplementation on blood pressure: a metaanalysis of randomized, double-blind, placebocontrolled trials. Am Heart J. 2011; 162(6): 959965.

22. Bertelsen RJ, Carlsen KC, Calafat AM, Hoppin JA, Håland G, Mowinckel P, Carlsen KH, Løvik M. Urinary biomarkers for phthalates associated with asthma in Norwegian children. Environ Health Perspect. 2013; 121(2): 251-256.

23. United State Consumer Product Safety Commission (US-CPSC). Chronic Hazard Advisory on Diisononyl Phthalate "Human risk is therefore seen as negligible" US-CPSC report. 2001; p. 87. 
24. Kannabiran K, Abirami M, Subashini J. Cytotoxic Activity of Bioactive Compound 1, 2- Benzene Dicarboxylic Acid, Mono 2- Ethylhexyl Ester Extracted from a Marine Derived Streptomyces sp. VITSJK8. Int J Mol Cell Med. 2014; 3(4): 246-254.

25. Nagaki M, Miyata K, Musashi T, Kawakami J, Ohya N, Sagami H. Insect pheromonelike activity of several isoprenoids against Phyllonorycter ringoniella (Matsumura). Trans Mat Res Soc. Jpn. 2009; 34(3): 575-578.

26. Derengowski LS, De-Souza-Silva C, Braz SV, Mello-De-Sousa TM, Báo SN, Kyaw CM, SilvaPereira I. Antimicrobial effect of farnesol, a Candida albicans quorum sensing molecule, on Paracoccidioides brasiliensis growth and morphogenesis. Ann Clin Microbiol Antimicrob. 2009; 8: 13.
27. Council of the European Communities (CEC). Council directive on the approximation of the laws of the member states relating to cosmetic products 27 July 1976, ref. (76/768/eec), 1976.

28. Hornby JM, Jensen EC, Lisec AD, Tasto JJ, Jahnke B, Shoemaker R, Dussault P, Nickerson KW. Quorum sensing in the dimorphic fungus Candida albicans is mediated by farnesol. Appl Environ Microbiol. 2001; 67(7): 2982-2992.

29. Joo JH, Jetten AM. Molecular mechanisms involved in farnesol-induced apoptosis. Cancer Lett. 2010; 287(2): 123-135.

30. Abbasi A, Mostafaie A, Bahrami G, Mansouri K, Sisakhtnejad S. The effect of cis and trans vaccenic acids on expression of ICAM-1 and VCAM-1 in human microvascular endothelial cells (HMEC). J Rep Phermaceut Sci. 2015; 4(1): 65-74.

Received 13.11.2017 